\title{
Feline Immunodeficiency Virus
}

National Cancer Institute

\section{Source}

National Cancer Institute. Feline Immunodeficiency Virus. NCI Thesaurus. Code C14288.

A lentivirus causing acquired immunodeficiency in cats. The FIV virus is transmitted in the saliva or blood, commonly through the bite wound from an infected cat. Strictly a feline disease, FIV cannot be transmitted to humans. 